\title{
ANALISIS KEMAMPUAN BERPIKIR KREATIF MATEMATIS TERHADAP SOAL-SOAL OPEN ENDED
}

\author{
Dian Nopitasari \\ Universitas Muhammadiyah Tangerang, Jl. Perintis Kemerdekaan 1/33, \\ d_novietasari@yahoo.com
}

\begin{abstract}
ABSTRAK
Tujuan penelitian ini adalah untuk mengetahui tingkat kemampuan berpikir kreatif matematis mahasiswa dalam menyelesaikan soal-soal open-ended pada mata kuliah matematika diskrit. Penelitian ini menggunakan metode kualitatif deskriptif. Populasi dalam penelitian ini adalah mahasiswa semester III Pendidikan Matematika UMT. Sampel diambil dengan teknik norm referenced evaluation yaitu mahasiswa di semester III-A3 yang memiliki kemampuan matematis tinggi, sedang dan rendah. Instrumen yang digunakan meliputi tes kemampuan berpikir kreatif, lembar observasi dan pedoman wawancara. Hasil analisis data menunjukkan bahwa mahasiswa dengan kategori tingkat berpikir kreatif matematis sedang dengan presentase responden adalah $84,61 \%$, kategori tingkat berpikir kreatif matematis sangat rendah dengan presentase $12,82 \%$, kategori tingkat berpikir kreatif matematis tidak kreatif dengan presentase 2,56\%. Dari hasil tersebut maka didapatkan rata-rata kategori kemampuan berpikir kreatif matematis mahasiswa semester III-A3 adalah 67,94 dengan tingkat kategori sedang.
\end{abstract}

Kata kunci: Kemampuan Berpikir Kreatif Matematis, Open Ended.
ABSTRACT
The purpose of this study is to determine the level of students' mathematical creative thinking ability in solving open-ended problems in discrete mathematics courses. This research uses descriptive qualitative method. The population in this research is the third semester students of Mathematics Education UMT. The sample was taken by norm referenced evaluation technique that is students in semester III-A3 who have high, medium and low mathematical ability. The instruments used include creative thinking ability tests, observation sheets and interview guides. The result of data analysis shows that the students with the category of creative mathematical thinking level with the percentage of respondents is $84.61 \%$, the category of mathematical creative thinking level is very low with $12.82 \%$ percentage, the level of creative creativity level is not creative with $2.56 \%$ percentage. From the result, we get the average category of students' mathematical creative thinking ability in the third semester-A3 is 67,94 with medium category level.

Keywords: Mathematical Creative Thinking Ability, Open Ended.

\section{How to Cite: Nopitasari, D. (2017). Analisis Kemampuan Berpikir Kreatif Matematis Terhadap Soal-soal Open Ended. Mathline: Jurnal Matematika dan Pendidikan Matematika, Vol.2, No.2, 195-202.}

\section{PENDAHULUAN}

Perkembangan zaman yang semakin kompleks, fungsi pengajaran matematika untuk mempersiapkan peserta didik dalam berpikir logis, kreatif, rasional, cermat, efisien, 
semakin berat, seorang guru pun harus lebih profesional dalam meningkatkan kreativitas peserta didik yang beragam melalui latihan-latihan pemecahan masalah. Berpikir kreatif merupakan masalah penting dalam belajar matematika, banyak guru disekolah dasar atau menengah masih kurang memperhatikan kemampuan ini. Dengan mengetahui kemampuan dan proses berpikir kreatif siswa, guru memperoleh wawasan yang luas tentang potensi dan bakat yang dimiliki peserta didiknya (Fardah, 2012).

Salah satu kelemahan proses pembelajaran yang dilaksanakan para guru adalah kurang adanya usaha pengembangan kemampuan berpikir kreatif matematis siswa. Sedangkan dalam proses belajar harus ada peningkatan kemampuan berpikir. Peningkatan kemampuan berpikir siswa itu melalui fakta-fakta atau pengalaman siswa sebagai bahan untuk memecahkan masalah yang diajukan. Dalam belajar bukan hanya sekedar siswa dapat menguasai sejumlah materi pembelajaran yang disampaikan oleh guru akan tetapi bagaimana siswa dapat mengembangkan gagasan-gagasan dan ide-ide yang mereka miliki. Pengembangan gagasan-gagasan dan ide-ide didasarkan pada kemampuan anak untuk mendeskripsikan hasil pengamatan mereka terhadap berbagai fakta dan data yang mereka peroleh dalam kehidupan sehari-hari.

Kemampuan berpikir kreatif matematis adalah kemampuan siswa dalam memahami masalah dan menemukan penyelesaian dengan strategi atau metode yang bervariasi (divergen). Meningkatkan kemampuan berpikir kreatif matematis artinya menaikan skor kemampuan siswa dalam memahami masalah, kefasihan, fleksibilitas, dan kebaruan penyelesaian masalah. Siswa dinyatakan memahami masalah bila menunjukan apa yang diketahui dan apa yang ditanyakan. Siswa memiliki kefasihan dalam menyelesaikan masalah bila dapat menyelesaikan soal dengan jawaban bermacam-macam yang benar secara logika. Siswa memiliki fleksibilitas dalam menyelesaikan masalah bila dapat menyelesaikan soal dengan dua cara atau lebih yang berbeda dan benar. Siswa memiliki kebaruan dalam menyelesaikan masalah bila dapat membuat jawaban yang berbeda dari jawaban sebelumnya atau yang umum diketahui siswa.

Untuk itu diperlukan cara penyelesaian yang sesuai dengan keadaan peserta didik yang beragam salah satunya adalah dengan cara penyelesaian mengunakan soal-soal terbuka (open-ended). Soal-soal terbuka (open-ended) adalah salah satu alternatif penyelesaian yang lebih memfasilitasi aktivitas dan kreatifitas peserta didik dalam menyelesaikan masalah-masalah dalam soal-soal tebuka (open-ended), penyelesaian masalah melalui pemberian soal-soal terbuka akan menjadi penyelesaian yang cukup kuat untuk mengembangkan kemampuan pemahaman konsep matematika, penalaran matematika, pemecahan masalah, dan komunikasi matematika. Penyelesaian dengan 
menggunakan soal-soal terbuka akan memberi makna positif bagi pencapaian tujuan pembelajaran matematika yang lebih tinggi. Pengembangan soal terbuka dimaksudkan untuk mengevaluasi kemampuan berpikir tingkat tinggi (Becker \& Shimada, 1997).

Menurut Takahashi (Mahmudi, 2008), terdapat beberapa manfaat dari penggunaan soal terbuka dalam pembelajaran matematika, yaitu sebagai berikut:

a. Siswa menjadi lebih aktif dalam mengekspresikan ide-ide mereka.

b. Siswa mempunyai kesempatan lebih untuk secara komperhensif menggunakan pengetahuan dan keterampilan mereka

c. Siswa mempunyai pengalaman yang kaya dalam proses menemukan dan menerima persetujuan dari siswa lain terhadap ide-ide mereka.

Kegiatan pembelajaran yang menerapkan soal-soal terbuka (open-ended), peserta didik dibawa untuk menjawab permasalahan dengan banyak cara sehingga peserta didik dapat meningkatkan potensi intelektual dan pengalaman siswa dalam proses menemukan sesuatu yang baru. Peserta didik diberi keleluasaan menghubungkan pengetahuan yang telah dimiliki dengan materi yang sedang dipelajari untuk menyelesaikan masalah. Dengan penyelesaian mengunakan soal-soal terbuka (open-ended), proses berpikir peserta didik dalam menghubungkan materi yang satu dengan materi yang lain dapat diamati. Cara ini menyajikan masalah yang memiliki metode atau penyelesaian yang benar lebih dari satu sehingga peserta didik dimungkinkan untuk memperoleh pengetahuan/pengalaman, menemukan, mengenali, dan memecahkan masalah dalam berbagai cara, sesuai dengan kemampuan masing-masing (Japar, 2009).

Penyelesaian soal matematika diskrit masih mengunakan cara biasa untuk mengerjakan soal latihan. Akibatnya peserta didik jarang mengasah kemampuan berpikir kreatif matematis. Sehingga penyelesaian yang kaku tampak dalam aktifitas penyelesaian masalah terhadap soal yang diberikan. Peserta didik mudah melupakan materi yang telah disampaikan di kelas, kurangnya konsep matematika dalam mengerjakan soal-soal menjadikan peserta didik beranggapan bahwa hanya satu penyelesaian dan cara menyelesaikan masalah. Diperoleh data siswa melalui wawancara yang dilakukan berupa persentase di kelas VIII yaitu: mahasiswa yang dapat memahami informasi masalah matematika dengan baik yaitu 40\%, mahasiswa yang dapat menyelesaikan jawaban dari persoalan matematika dengan berbagai cara dengan bermacam-macam jawaban yaitu 15\%, mahasiswa dapat membuat metode baru mengunakan konsep matematika yang berbeda sekitar 3\%, mahasiswa tidak memahami konsep matematika dan sering kebingungan 
menyelesaikan masalah sebanyak 42\%. Berdasarkan kondisi tersebut, peneliti menggunakan soal-soal terbuka (open-ended) dalam menyelesaikan masalah yang diharapkan dapat menganalisa kemampuan berpikir kreatif peserta didik lebih terarah secara optimal.

Berdasarkan uraian yang telah dipaparkan di atas, peneliti menyusun rumusan masalah yang akan menjadi fokus penelitian kali ini, yaitu sejauhmana tingkat kemampuan berpikir kreatif matematis peserta didik terhadap soal-soal terbuka (open-ended) dalam mata kuliah matematika diskrit. Tujuan penelitian ini adalah mengetahui tingkat kemampuan berpikir kreatif siswa melalui indikator kemampuan berpikir kreatif matematis dalam menyelesaikan soal-soal terbuka (open-ended).

\section{METODE PENELITIAN}

Penelitian ini menggunakan penelitian kualitatif dengan jenis metode penelitian kualitatif deskriptif yang ditujukan untuk mendeskripsikan kemampuan berpikir kreatif matematis mahasiswa. Prosedur penelitian yang digunakan peneliti terdiri dari empat tahap yaitu perencanaan, tahap pelaksanaan, tahap analisis data, dan pembuatan laporan.

\section{Tahap perencanaan}

Kegiatan yang dilakukan dalam tahap perencanaan adalah sebagai berikut:

a. Menyusun instrumen tes kemampuan berpikir kreatif matematis dan pedoman wawancara berdasarkan indikator kemampuan berpikir kreatif matematis.

b. Melakukan validasi instrumen tes berpikir kreatif matematis.

c. Menganalisis hasil validasi instrumen tes kemampuan berpikir kreatif matematis kemudian merevisi instrumen jika kurang layak.

\section{Tahap Pelaksanaan}

Kegiatan dalam tahap pelaksanaan meliputi:

a. Memberikan soal yang berbentuk berpikir kreatif matematis dan wawancara kepada subjek penelitian serta menganalisis hasil tes dan wawancara tersebut.

\section{Tahap Analisis Data}

Kegiatan yang dilakukan pada tahap ini meliputi :

a. Melakukan analisis data yang telah didapatkan pada tahap pelaksanaan (hasil tes dan wawancara).

b. Menarik kesimpulan atau verifikasi 


\section{Pembuatan Laporan}

Pada tahap ini peneliti membuat laporan dari hasil penelitian yang didapatkan di lapangan.

Sumber data utama dalam penelitian kualitatif ialah kata-kata dan tindakan, selebihnya adalah data tambahan seperti dokumen dan lain-lain. Kata-kata dan tindakan orang-orang yang diamati atau diwawancarai merupakan sumber data utama dalam penelitian kualitatif. Sumber data utama dicatat melaui catatan tertulis atau melalui perekaman video/ audio tapes.

\section{HASIL DAN PEMBAHASAN}

Penggunaan soal-soal terbuka (open-ended) memberikan solusi yang baik bagi tercapainya pembelajaran yang efektif. Peserta didik mampu mengespresikan ide-ide mereka dalam menjawab soal-soal terbuka (open-ended) dalam pembelajaran matematika hal ini sesuai dengan teori yang dikemukaan oleh Becker \& Shimada (1997) yaitu dimana peserta didik dapat menjelaskan soal-soal yang memerlukan pembuktian dapat dirubah oleh peserta didik dalam menemukan hubungan dari sifat-sifat/ unsur-unsur, siswa mampu menemukan suatu aturan matematika dari soal-soal terbuka (open-ended) yang diberikan.

Keberagaman kemampuan berpikir kreatif matematis peserta didik dalam penelitian ini akan diukur melalui tes tertulis yang telah diujikan melalui tahap validitas dalam menyelesaikan soal-soal terbuka (open-ended) yang diberikan di kelas, peserta didik yang memiliki kemampuan berpikir kreatif matematis akan digolongkan berdasarkan tingkat kemampuan berpikirnya, kemampuan peserta didik dalam memahami masalah, menemukan pemecahan masalah. Setelah penelitian dilaksanakan, selanjutnya jawaban peserta didik dikoreksi dan dikelompokkan berdasarkan tingkat kemampuan berpikir kreatif matematis, seperti pada tabel berikut:

Tabel 1. Tingkat Kemampuan Berpikir Kreatif Matematis

\begin{tabular}{lll}
\hline TKBK & \multicolumn{1}{c}{ Indikator yang harus terpenuhi } & Kategori TKBK \\
\hline TKBK 4 & $\begin{array}{l}\text { keterampilan berpikir lancar (fluency), berpikir luwes } \\
\text { (flexibility), berpikir orisinil (originality) dan } \\
\text { keterampilan merinci (elaboration). } \\
\text { keterampilan berpikir lancar (fluency) dan berpikir } \\
\text { orisinil (originality) atau berpikir luwes (flexibility) } \\
\text { dan keterampilan merinci (elaboration). } \\
\text { berpikir luwes (flexibility) atau berpikir orisinil } \\
\text { (originality). }\end{array}$ & Sedang \\
TKBK 2 3 Rendah \\
TKBK 1 & $\begin{array}{l}\text { keterampilan berpikir lancar (fluency). } \\
\text { TKBK 0 }\end{array}$ & $\begin{array}{l}\text { Sangat Rendah } \\
\text { Tidak Kreatif }\end{array}$ \\
\hline
\end{tabular}


Setelah hasil tes tertulis responden dikoreksi, diperoleh aspek-aspek apa saja yang dapat dipenuhi oleh tiap responden, aspek yang dapat dipenuhi oleh responden dapat meliputi aspek kemampuan berpikir lancar (fluency) yaitu responden dapat menjawab pertanyaan dengan memahami masalah yang diberikan mengajukan solusi di depan kelas, kemampuan berpikir luwes (flexibility) yaitu responden dapat berdiskusi dengan kelompoknya sambil memperagakan konsep menggunakan jawaban yang bervariasi, keterampilan berpikir orisinil (originality) dan keterampian responden dalam (memerinci/ elaboration) jawaban permasalahan soal-soal terbuka (open-ended) yang diberikan. Dari itu dapat diketahui tingkat kemampuan berpikir kreatif responden. Adapun tingkat kemampuan berpikir kreatif yang dicapai adalah sebagai berikut:

Tabel 2. Jumlah dan Presentase Responden tiap TKBK

\begin{tabular}{cccc}
\hline TKBK & Jumlah & Presentase(\%) \\
\hline 0 & 1 & 2,56 \\
1 & 5 & 12,82 \\
2 & 0 & 0,00 \\
& 3 & 33 & 84,61 \\
& 4 & 0 & 0,00 \\
Total & $\mathbf{3 9}$ & $\mathbf{1 0 0}$ \\
\hline
\end{tabular}

Dari tabel diatas sebagian besar 33 orang peserta didik atau sebesar 84,61\% berada pada TKBK 3 dengan memenuhi aspek kemampuan berpikir lancar (fluency) dan kemampuan berpikir orisinil (originality) atau kemampuan berpikir luwes (flexibility) atau keterampilan memerinci (elaboration). Peserta didik menempati TKBK 1 dengan presentase $12,82 \%$ sebanyak 5 orang peserta didik, pada tingkat ini peserta didik hanya mampu memenuhi aspek keterampilan berpikir lancar (fluency) yaitu peserta didik dapat memberikan lebih dari satu alternatif jawaban atau dapat membuat lebih dari satu soal yang beragam solusi dari soal-soal terbuka (open-ended) yang yang diberikan. Selanjutnya sejumlah 1 peserta didik tidak dapat memenuhi satupun aspek kemampuan berpikir kreatif maka peserta didik pada TKBK 0 memiliki presentase $2,56 \%$. Sedangkan untuk TKBK 2 dan TKBK 4 tidak ditemukan peserta didik yang memenuhi karakteristik pada tingkat kemampuan berpikir kreatif matematis tersebut.

Peserta didik dengan kategori tingkat berpikir kreatif matematis sedang dihuni sebanyak 33 orang peserta didik dengan presentase responden tiap TKBK adalah 84,61\% dan tingkat kemampuan berpikir kreatif matematis perindividu sebesar 75.00, kategori tingkat berpikir kreatif matematis sangat rendah sebanyak 5 orang siswa dengan presentase 
TKBK 12,82 \% dan tingkat kemampuan berpikir kreatif matematis perindividu 25.00, kategori tingkat berpikir kreatif matematis tidak kreatif sebanyak 1 peserta didik dengan presentase 2,56 \% dan tingkat kemampuan berpikir kreatif matematis memasuki perindividu 0.00 .

Dari data yang telah diperoleh peneliti di lapangan maka didapatkan kalsifikasi secara sederhana mengenai tingkat kemampuan berpikir kreatif matematis peserta didik terhadap soal-soal terbuka (open-ended) menggunakan grafik dengan keterangan yang terdapat di dalam grafik maka dapat dilihat sebaran berikut:

\begin{tabular}{|c|c|c|c|c|c|}
\hline \multirow{4}{*}{$\begin{array}{r}35 \\
30 \\
25 \\
20 \\
15 \\
10 \\
5 \\
0\end{array}$} & & & & & \\
\hline & & & & & 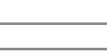 \\
\hline & & & & 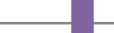 & \\
\hline & $\begin{array}{c}\text { Tidak } \\
\text { Kreatif }\end{array}$ & $\begin{array}{l}\text { Sangat } \\
\text { Rendah }\end{array}$ & Rendah & Sedang & Tinggi \\
\hline - TKBK 0 & 1 & & & & \\
\hline TKBK 1 & & 5 & & & \\
\hline TKBK 2 & & & 0 & & \\
\hline TKBK 3 & & & & 33 & \\
\hline TKBK 4 & & & & & 0 \\
\hline
\end{tabular}

Gambar 1. Diagram Hasil Analisis pengklasifikasian Tingkat Kemampuan Berpikir Kreatif

Implementasi/ penerapan soal-soal terbuka (open-ended) dapat mengukur kemampuan berpikir kreatif matematis peserta didik, walaupun disadari terdapat berbagai manfaat dari penggunaan soal-soal terbuka (open-ended) dalam penyelesaian soal-soal matematika, namun ada beberapa kendala dalam mempraktikannya. Tidak mudah bagi guru untuk dapat menerapkan soal-soal terbuka (open-ended), perlu berbagai strategi untuk dapat mempraktikan soal-soal terbuka. Selanjutnya diharapkan penggunaan soal terbuka dapat mengukur kemampuan berpikir kreatif matematis peserta didik lebih membudaya, sehingga akan menjadikan pembelajaran matematika lebih bermakna, karena dapat mengoptimalkan pengembangan potensi peserta didik. Soal-soal terbuka (open-ended) dirancang untuk menyelesaikan persoalan atau permasalahan dengan berbagai cara atau strategi. Dengan pemberian soal-soal terbuka (open-ended) memungkinkan peserta didik berperan aktif dalam menyelesaikan masalah tanpa harus terpaku pada cara yang sudah biasa dikenal. Soal-soal terbuka (open-ended) memberikan peluang kepada peserta didik 
untuk memberikan banyak pemecahan masalah dengan banyak strategi pemecahan masalah, sehingga dengan beragamnya jawaban yang diberikan peserta didik tersebut guru dapat mendeteksi kemampuan berpikir siswa.

\section{KESIMPULAN}

Hasil analisis kemampuan berpikir kreatif matematis terhadap soal terbuka ditentukan dengan menghitung rata-rata ketercapaian setiap individu. Peserta didik dengan kategori tingkat berpikir kreatif matematis sedang dihuni sebanyak 33 orang peserta didik dengan presentase responden tiap TKBK adalah 84,61\% dan tingkat kemampuan berpikir kreatif matematis perindividu mencapai 75.00, kategori tingkat berpikir kreatif matematis sangat rendah sebanyak 5 orang siswa dengan presentase TKBK 12,82\% dan tingkat kemampuan berpikir kreatif matematis perindividu mencapai 25.00, kategori tingkat berpikir kreatif matematis tidak kreatif sebanyak 1 peserta didik dengan presentase $2,56 \%$ dan tingkat kemampuan berpikir kreatif matematis memasuki perindividu mencapai 0.00. Dari hasil tersebut maka didapatkan rata-rata kategori kemampuan berpikir di semester IIIA3 dengan hasil 67,94 dengan tingkat kategori sedang.

Pengunaan dengan menggunakan soal-soal terbuka (open-ended) membuat peserta didik merasa senang, tertarik, tertantang, terbantu dan dapat menumbuhkan rasa kebersamaan dalam belajar oleh kegiatan belajar kelompok. Selain itu, selama proses belajar peserta didik juga terlihat tidak bosan belajar, juga terlihat antusias dalam melibatkan dirinya berperan aktif dalam suasana belajar yang terbuka dalam mengungkapkan pertanyaan dan gagasan.

\section{DAFTAR PUSTAKA}

Becker, J.P. \& Shimada, S. (1997). The Open-Ended Approach: A New Proposal for Teachimg Mathematics. Virginia: National Council of Teacher Mathematics.

Fardah, D. K. (2012). Analisis Proses dan Kemampuan Berpikir Kreatif Siswa dalam Matematika melalui Tugas Open-Ended. Jurnal Kreano. Volume 3 No. 2. 91-99.

Japar. (2009). Pembelajaran Matematika dengan Pendekatan Open-Ended. Jurnal LIPI, 1-

2. [Online]. Tersedia di: http://isjd.pdii.lipi.go.id/admin/jurnal/51085361.pdf [Diakses 15 Mei 2011].

Mahmudi, A. (2008). Mengembangkan Soal Terbuka (Open-Ended Problem dalam Pembelajaran Matematika, Makalah Disampaikan Pada Seminar Nasional Matematika dan Pendidikan Matematika FMIPA UNY pada hari Jumat, 28 November 2008. [Online]. Tersedia di: http://staffnew.uny.ac.id/upload/132240454/penelitian/Makalah+02+PIPM+2008+ Mengembangkan+Soal+Terbuka_.pdf [7 Oktober 2012]. 